\title{
KORELASI ANTARA MOTIVASI PESERTA DIDIK DENGAN HASIL BELAJAR KIMIA KELAS XI IPA SMA NEGERI SE-KECAMATAN TERNATE UTARA
}

\author{
Serna Hamid, Mohammad Wijaya ${ }^{1}$, Ramlawati ${ }^{2}$ \\ ${ }^{1,2}$ Dosen Program Pascasarjana Universitas Negeri Makassar \\ Email:sernahamid053@gmail.com
}

\begin{abstract}
ABSTRAK
Penelitian ini merupakan penelitian survey and ex-post facto yang bertujuan untuk mengetahui korelasi antara motivasi peserta didik dengan hasil belajar kimia kelas XI IPA SMA Negeri Se-Kecamatan Ternate Utara tahun pelajaran 2017/2018. Total populasi penelitian sebanyak 311 peserta didik dengan ukuran sampel sebanyak 175 peserta didik. Teknik penentuan sampel dilakukan dengan menggunakan propotional cluster random sampling. Pengambilan data penelitian menggunakan instrumen berupa angket terbuka dan tes. Data penelitian dianalisis menggunakan Software SPSS. Hasil penelitian menunjukkan bahwa korelasi antara motivasi peserta didik dengan hasil belajar kimia sangat kuat dengan niai yag diperoleh adalah 0,88 . Untuk uji hipotesis digunakan uji $t$, data yang diperoleh menunjukan $t_{\text {hitung }}>\mathrm{t}_{\text {tabel }}$ yaitu 8,23 >1,97 maka $\mathrm{H}_{0}$ ditolak dan $\mathrm{H}_{1}$ di terima sehingga dapat disimpulkan terdapat korelasi antara motivasi peserta didik dengan hasil belajar kimia.

Kata Kunci: motivasi, hasil belajar.
\end{abstract}

ABSTRACT
The study is a survey and ex-post facto which aims to determine the correlation between the motivation of students with chemistry learning outcomes grade XI IPA of State Senior High Schools in North Ternate District in the academic year 2017/2018. The total population of the study was 311 students with a sample size of 175 students. The sample determination technique is used propotional cluster random sampling. Retrieval of research data using an instrument in the form of an open questionnaire and test, research data were analyzed using SPSS Software. The results showed that the correlation between the motivation of students with chemistry learning outcomes was very strong with the value obtained was 0.88 . To test the hypothesis, the $t$ test is used, the data obtained shows $t_{\text {count }}>t$ table that the number is 8.23 $>1.97$ then $\mathrm{H}_{0}$ is rejected and $\mathrm{H}_{1}$ is accepted so that it can be concluded that there is a correlation between the motivation of students with chemistry learning outcomes.

Keywords: Motivation, Learning Achievement.

\section{PENDAHULUAN}

Undang-Undang No. 20 Tahun 2013 tentang sistem pendidikan nasional menjelaskan bahwa pendidikan adalah usaha sadar dan terencana untuk mewujudkan suasana belajar dan proses pembelajaran agar peserta didik secara aktif mengembangkan potensi dirinya untuk memiliki kekuatan spiritual keagamaan, pengendalian diri, kepribadian, kecerdasan, akhlak mulia, serta kecakapan yang diperlukan dirinya, masyarakat, bangsa dan Negara. Tujuan pendidikan nasional dapat terwujud apabila sistem pendidikan tidak hanya ditekankan pada hasil belajar peserta didik tetapi juga pada proses belajar dari peserta didik itu sendiri untuk menumbuhkan kemampuan peserta didik. Beberapa komponen pendidikan yang sangat berpengaruh dalam proses berpikir, bekerja dan bersikap kritis guna mengembangkan potensi pembelajaran yaitu pendidik, peserta didik, infrastruktur pendidikan dan lingkungan yang mendukung proses pembelajaran, sehingga pendidik dan peserta didikpun saling 
keterkaitan dalam melaksanakan proses pembelajaran untuk mencapai hasil yang didapat.

Pendidikan merupakan salah satu kebutuhan yang harus dimiliki seseorang, karena sangatlah berpengaruh dalam proses kehidupan. Dalam kemajuan bangsa yang mempengaruhi salah satunya adalah mutu pendidikan itu sendiri, karena mutu pendidikan yang tinggi dapat menghasilkan sumber daya manusia yang berkualitas. Pendidikan yang dimaksud adalah pendidikan yang bersifat formal maupun nonformal. Dalam pendidikan formal kita kenal dengan sekolah 12 tahun yaitu dimulai dari SD, SMP dan SMA. Dunia pendidikan juga kita kenal dengan kedisiplinan. Setiap peserta didik harus memiliki kedisiplinan yang tinggi untuk kemajuan pendidikan, tetapi semua itu butuh proses dalam belajar.

Pendidikan kimia memiliki potensi yang besar dan peranan strategis dalam menyiapkan sumber daya manusia yang berkualitas untuk menghadapi era globalisasi. Dalam mengahadapi era globalisasi maka peserta didik yang sebagai generasi penerus diharuskan untuk memiliki potensi pada diri masing-masing. Potensi ini dapat terwujud jika pendidikan kimia mampu memberikan pengalaman belajar kepada peserta didik sesuai dengan tuntutan zaman. Pengalaman belajar ini diperoleh peserta didik dari proses pembelajaran di sekolah. Dalam proses pembelajaran dapat dilihat melalui proses penilaian hasil belajar peserta didik. Hasil belajar perserta didik banyak dipengaruhi dari berbagai faktor yaitu faktor internal dan eksternal.

Salah satu faktor internal yang mempengaruhi hasil belajar adalah motivasi peserta didik dalam mempelajari materi kimia. Berdasarkan pengamatan yang telah dilakukan di salah satu SMA Negeri Kecamatan Ternate Utara, terlihat peserta didik dalam mengikuti proses pembelajaran kimia masih kurang termotivasi dalam belajar. Hal ini terlihat saat pelajaran berlangsung, sedikit peserta didik yang antusias dalam proses belajar Untuk hasil peserta didik diketahui dari wawancara yang dilakukan kepada salah satu guru, mengatakan nilai hasil belajar peserta didik rata-rata di bawah nilai KKM yaitu 75 . Hasil belajar kimia yang diperoleh oleh peserta didik dibawah rata-rata karena sangat rendah motivasi dalam belajar kimia yang dimiliki peserta didik, dimana diketahui bahwa motivasi adalah salah satu faktor yang berpengaruh pada hasil belajar karena motivasi termasuk dalam faktor internal.

Motivasi sangat berhubungan erat dengan hasil belajar, karena dengan adanya motivasi maka peserta didik lebih minat dalam belajar kimia, lebih tekun dalam belajar, ulet dalam mengerjakan sesuatu, tidak pernah bosan dengan terus belajar. Hal ini sejalan dengan penelitian yang dilakukan oleh Lestari (2014) terdapat hubungan positif yang signifikan antara motivasi dengan hasil belajar peserta didik. Peserta didik yang memiliki motivasi belajar yang tinggi cenderung akan mempunyai sikap positif untuk berhasil (Slameto,2010). Dalam proses pembelajaran motivasi sangat besar peranannya terhadap hasil belajar. Karena dengan adanya motivasi dapat menumbuhkan minat belajar peserta didik. Hal ini diperkuat dengan penelitian sebelumnya yang dilakukan oleh Ryan et al (2007) menunjukan bahwa motivasi peserta didik dapat mempengaruhi hasil kognitif. Jika motivasi peserta didik tinggi maka hasil kognitifya tinggi dan sebaliknya. Wardhana (2016) hasil penelitian menunjukan bahwa ada hubungan positif dan signifikan antara motivasi dengan hasil belajar.

Penelitian yang dilakukan oleh Jeffrey and Zein (2017) menunjukan bahwa adanya korelasi antara kedisiplinan dan motivasi terhadap hasil belajar. Dapat dilihat dari guru harus mampu menciptakan kondisi bagi peserta didik sehingga 
kedisiplinan dan motivasi peserta didik lebih baik dan hasil belajar yang lebih baik.

Berdasarkan hasil penelitian telah dilakukan maka peneliti tertarik ingin melakukan penelitian dengan judul "Korelasi antara Motivasi Peserta Didik dengan Hasil Belajar kimia Kelas XI IPA SMA Negeri Se-Kecamatan Ternate Utara".

\section{METODE PENELITIAN}

Jenis penelitian ini adalah penelitian "ex-post facto" karena faktor yang dikumpulkan sudah ada sebelumnya pada diri responden atau gejala muncul tanpa adanya perlakuan, dan bersifat "korelasional" karena diselidiki korelasi antar variabel. Penelitian ini akan menerangkan korelasi antara motivasi peserta didik dengan hasil belajar kimia.

Populasi dalam penelitian ini yaitu seluruh peserta didik kelas XI IPA SMA Negeri Se-Kecamatan Ternate Utara tahun ajaran 2017/2018 yang terdiri dari 3 SMA yaitu SMA Negeri 4 Kota Ternate, SMA Negeri 5 Kota Ternate dan SMA Negeri 8 Kota Ternate. Pengambilan sampel dalam penelitian ini akan menggunakan teknik propotinal cluster random sampling. Jadi dari populasi sebanyak 311 peserta didik, banyaknya sampel yang digunakan dalam penelitian ini adalah 175 peserta didik.

Untuk memperoleh skor variabel penelitian, akan digunakan 2 instrumen yang terdiri atas dua bentuk, yaitu angket dan tes. Angket dalam penelitian ini berupa angket motivasi peserta didik. Adapun instrumen dalam bentuk tes yang akan digunakan yaitu tes hasil belajar peserta didik pada mata pelajaran kimia.

Validitas yang digunakan peneliti dalam penlitian ini yaitu validitas isi dan validitas konstruk. Validitas sering digunakan dalam penelitian hasil belajar. Tujuannya untuk mengetahui sejauh mana peserta didik menguasai materi pelajaran yang telah dipelajari.

Pegumpulan data akan dilakukan secara langsung artinya data diperoleh dengan meminta responden untuk mengisi angket tanpa perantara orang lain. Data motivasi peserta didik akan diperoleh melalui pemberian angket kepada setiap responden (peserta didik) yang terpilih sebagai sampel. Angket tersebut selanjutnya diisi oleh responden, kemudian diperiksa dan diberi skor berdasarkan alternatif pilihan yang dipilih oleh responden. Data hasil belajar kimia peserta didik akan diperoleh melalui pemberian tes hasil belajar kepada peserta didik yang terpilih sebagai sampel penelitian. Tes tersebut berbentuk pilihan ganda yang dibuat berdasarkan indikator-indikator mata pelajaran kimia yang telah dipelajari peserta didik dalam proses belajar mengajar khususnya pada materi asam basa, titrasi asam basa dan hidrolisis garam.

Data yang telah dikumpulkan selanjutnya akan dianalisis menggunakan statistika deskiptrif dan statistika inferensial. Statistik deskriptif adalah statistik yang digunakan untuk menganalisis data dengan cara mendeskripsikan atau menggambarkan data yang telah diperoleh sebagaimana adanya, tanpa bermaksud membuat kesimpulan yang berlaku umum (Sugiyono, 2008). Analisis deskriptif digunakan untuk mendeskripsikan karakteristik hasil belajar peserta didik. Untuk pengkategorian skor hasil belajar digunakan kriteria berdasarkan pengkategorian skala tiga yaitu rendah, cukup dan tinggi (Azwar, 2010).

Analisis deskriptif yang akan dilakukan terhadap data motivasi perserta didik dikategorikan secara kualitatif. Statistik inferensial dipakai untuk keperluan pengujian hipotesis, yakni digunakan analisis korelasi pearson dan analisis regresi ganda.

\section{HASIL DAN PEMBAHASAN}

Hasil analisis deskriptif yang berkaitan dengan nilai variabel motivasi pada peserta didik kelas XI IPA SMA SeKecamatan Ternate Utara disajikan pada Tabel 1, kategori motivasi peserta didik disajikan dalam Tabel 2 dan 
deskripsirespon peserta didik tentang motivasi disajikan pada tabel 3 .

Tabel 1 Statistik Nilai Motivasi Peserta Didik

\begin{tabular}{cc}
\hline Satistik & Nilai Statistik \\
\hline Ukuran Sampel & 175 \\
Skor Tertinggi & 91,07 \\
Skor Terendah & 53,57 \\
Skor Rata-rata & 71,29 \\
Nilai Ideal & 100,00 \\
Standar Deviasi & 8,67 \\
\hline
\end{tabular}

Tabel 2 Distribusi Presentase Nilai Motivasi Peserta Didik

\begin{tabular}{cccc}
\hline Interval & $\begin{array}{c}\text { Frekuens } \\
\mathrm{i}\end{array}$ & $\begin{array}{c}\text { Persentas } \\
\mathrm{e}(\%)\end{array}$ & $\begin{array}{c}\text { Kategor } \\
\mathrm{i}\end{array}$ \\
\hline $\begin{array}{c}78,14 \\
-100\end{array}$ & 39 & 22,2 & Tinggi \\
46,87 & & & \\
- & 137 & 77,8 & Cukup \\
78,13 & & & \\
$25-$ & 0 & 0 & Rendah \\
46,86 & 0 & & \\
\hline $\begin{array}{c}\text { Jumla } \\
\text { h }\end{array}$ & 175 & 100 & \\
\hline
\end{tabular}

Tabel 3 Deskripsi Respon Pesera Didik tentang Motivasi

\begin{tabular}{|c|c|c|}
\hline No & Pernyataan & Alasan Peserta Didik \\
\hline 1 & $\begin{array}{l}\text { Saya senang } \\
\text { belajar kimia }\end{array}$ & $\begin{array}{lr}\text { Guru } & \text { mengajar } \\
\text { dengan } & \text { santai } \\
\text { membuat } & \text { suasana } \\
\text { kelas yang } & \text { nyaman } \\
\text { sehingga } & \text { mudah } \\
\text { untuk } & \text { memahami } \\
\text { materi } & \text { yang } \\
\text { diajarkan dan } & \text { sering } \\
\text { dikaitkan } & \text { dengan } \\
\text { kehidupan } & \text { sehari- } \\
\text { hari. } & \end{array}$ \\
\hline 2 & $\begin{array}{l}\text { Bagi raya } \\
\text { belajar kimia } \\
\text { membosankan }\end{array}$ & $\begin{array}{l}\text { Peserta didik merasa } \\
\text { bosan ketika materi } \\
\text { yang diajaran } \\
\text { dianggap sulit untuk } \\
\text { memahami }\end{array}$ \\
\hline 3 & $\begin{array}{l}\text { Ketika saya } \\
\text { mengerjakan } \\
\text { tugas kimia } \\
\text { saya akan }\end{array}$ & $\begin{array}{lr}\text { Peserta } & \text { didik } \\
\text { berusaha } & \text { mencari } \\
\text { persoalan } & \text { yang } \\
\text { diberikan } & \text { oleh } \\
\text { guru }\end{array}$ \\
\hline
\end{tabular}

$\begin{array}{ll}\text { mengerjakan } & \text { karena dianggap } \\ \text { hingga selesai } & \text { tanggungjawab }\end{array}$

menjadi seorang

peserta didik

$4 \quad$ Saya kurang Peserta didik selalu berusaha giat dalam belajar dengan giat karena senang untuk dengan belajar kimia memahami dan keinginan untuk dan mengerti belajar kimia yang semua materi sangat besar.

kimia

5 Apabila saya Peserta didik selalu menemui soal mengerjakan soal kimia yang yang dianggap sulit sulit maka untuk mengetahui saya akan kemampuan dalam berusaha memahami materi untuk kimia.

mengerjakan

6 Saya malas Peserta didik mengerjakan memiliki tekat yang tugas kimia tinggi, sesulit apapun yang sulit tetap mereka tetap berusaha.

7 Jika nilai Peserta didik terus kimia saya belajar untuk jelek, maka meningkatkan saya akan kemampuan terus rajin sehingga nilai yang belajar agar diperoleh lebih baik nilai kimia sebelumnya. saya menjadi baik.

8 Saya merasa Peserta didik merasa putus asa jika kecewa karena hasil tugas kimia yang diperoleh tidak yang saya sesuai dengan kerjakan keinginan mereka. jawabannya salah

9 Saya selalu Peserta didik merasa mengerjakan lebih percaya diri sendiri tugas jika dikerjakan yang sesuai kemampuan diberikan sendiri dan menguji guru pemahaman materi kimia. 
10 Jika diberikan Peserta didik tugas kimia menyontek ketika saya tugas yang mereka mencontek kerjakan belum milik teman terselesaikan, karena pemahaman mereka belum sampai pada tahap tersebut.

11 Saya senang Peserta didik lebih mengerjakan merasa mudah tugas kimia mengerjakan soal yang yang sama karena diberikan sudah mengertahui dengan jenis cara soal yang penyelesaiannya. sama

12 Saya merasa Peserta didik lebih bosan ketika senang materi guru diulang-ulang karena menjelaskan mereka lebih materi secara memahaminya.

berulangulang

13 Mengerjakan Peserta didik dapat tugas kimia mengetahui membuat kemampuan pada hasil belajar diri sendiri dan dapat saya lebih dimanfaatkan ilmu baik dan saya yang telah menjadi didapatkan.

memahami Walaupun beberapa materi yang peserta didik tidak diajarkan menyukai tugas yang diberikan karena kurang menyukai pelajaran kimia.

14 Saya mengerjakan tugas kimia tetapi hasil saya masih rendah karena saya belum memahami Peserta didik sering mengerjakan tugas kimia tetapi jawaban sering salah, karena tidak memperhatikan dengan baik sehingga salah materi dengan baik

\section{Hasil Analisis Statistika Inferensial}

Berikut ini disajikan hasil analisis statistika inferensial yang terdiri atas uji asumsi dan uji hipotesis.

a. Uji Asumsi

1) Uji Multikolinearitas

Hasil output dari uji multikolinearitas menggunakan program SPSS disajikan dalam Tabel 4.

Tabel 4 Hasil Uji Multikolinearitas

\begin{tabular}{cc}
\hline Variabel & $\begin{array}{c}\text { Collinearity } \\
\text { Statistics }\end{array}$ \\
\cline { 2 - 2 } & VIF \\
\hline Motivasi Belajar & 2,58 \\
\hline Berdasarkan hasil pengujian dengan
\end{tabular}

SPSS diperoleh nilai Variance Inflation Factor (VIF) variabel Motivasi peserta didik lebih kecil dari $5(V I F<5)$, sehingga dapat dikatakan bahwa antar variabel tidak terjadi persoalan multikolinearitas.

2) Uji Linearitas

Uji linearitas bertujuan untuk mengetahui apakah dua variabel mempunyai hubungan yang linear atau tidak secara signifikan. Pada taraf signifikan 0,05 , dua variabel dikatakan mempunyai hubungan linear nilai signifikansi lebih besar dari 0,05. Tabel 5 disajikan hasil output dari uji linearitas antara variabel bebas dengan variabel terikat menggunakan SPSS.

Tabel 5 Hasil Uji Linearitas Antara Variabel Motivasi Peserta Didik dengan

Hasil Belajar

\begin{tabular}{lc}
\hline \multicolumn{1}{c}{ Variabel } & $\begin{array}{c}\text { Deviation from } \\
\text { Linearity (Sig.) }\end{array}$ \\
\hline Motivasi Belajar dengan & 0,11 \\
Hasil Belajar & \\
Berdasarkan Tabel 4 diperoleh nilai \\
signifikansi (Deviation from Linearity) \\
lebih besar dari $\alpha=0,05$ yang berarti \\
terdapat hubungan linear secara signifikan \\
antara variabel motivasi peserta didik \\
dengan hasil belajar.
\end{tabular}

\section{b. Uji Hipotesis}

Pengujian hipotesis menggunakan analisis korelasi pearson dan analisis regresi ganda yaitu uji t. Hasil uji hipotesis dengan korelasi pearson dan regresi ganda 
menggunakan program SPSS disajikan dalam Tabel 6 dan Tabel 7.

Tabel 6 Hasil Analisis Korelasi Pearson

\begin{tabular}{lc}
\hline \multicolumn{1}{c}{ Variabel } & $\begin{array}{c}\text { Pearson } \\
\text { Correlation }\end{array}$ \\
\hline $\begin{array}{l}\text { Motivasi Belajar } \\
\text { dengan Hasil Belajar }\end{array}$ & 0,88 \\
\hline
\end{tabular}

Tabel 7 Hasil Analisis Regresi Ganda (Uji t)

\begin{tabular}{ll}
\hline \multicolumn{1}{c}{ Variabel } & Uji t \\
\hline Motivasi Belajar dengan & 8,23 \\
Hasil Belajar & \\
\hline
\end{tabular}

Setelah uji hipotesis maka dilakukan analisis jalur untuk melihat pengaruh satu variabel bebas terhadap variabel terikat berdasarkan indikator. Hasil analisis jalur ditunjukkan pada Tabel 8.

Tabel 8 Hubungan Indikator Motivasi Peserta Didik dengan Hasil Belajar

\begin{tabular}{lcc}
\hline \multicolumn{1}{c}{ Indikator } & Beta & Sig. \\
\hline Minat & 0,227 & 0,000 \\
Tekun/Kegigihan & 0,249 & 0,000 \\
Usaha & 0,069 & 0,156 \\
Ulet & 0,301 & 0,000 \\
Mandiri & 0,193 & 0,245 \\
Cepat Bosan & 0,206 & 0,000 \\
Prestasi & 0,150 & 0,007 \\
\hline
\end{tabular}

\section{Pembahasan Hasil Penelitian}

Hasil analisis antara motivasi dengan hasil belajar peserta didik kelas XI IPA SMA Negeri Se-Kecamatan Ternate Utara berada pada kategori cukup dengan persentase $77,8 \%$. Dimana motivasi merupakan salah satu faktor yang sangat berpengaruh dengan hasil belajar.

Berdasarkan uji hipotesis pada Tabel 4.13, hasil analisis korelasi pearson diperoleh sebesar 0,88 yang menunjukan bahwa terdapat korelasi antara motivasi dengan hasil belajar peserta didik yang sangat kuat. Pada Tabel 4.14 hasil analisis regresi ganda dengan nilai thitung $=8,23$ lebih besar dari $\mathrm{t}_{\text {Tabel }}=1,97$, sehingga dapat disimpulkan bahwa $\mathrm{H}_{0}$ ditolak dan $\mathrm{H}_{1}$ diterima artinya terdapat hubungan antara motivasi dengan hasil belajar peserta didik. Sejalan dengan penelitian yang dilakukan oleh Az-Zahro \& Khairunnisa (2008) yang menyatakan bahwa terdapat hubungan yang signifikan pada kategori sangat kuat antara motivasi dengan prestasi belajar. Ryan et al (2007) mengatakan motivasi peserta didik dapat mempengaruhi hasil kognitifnya, jika motivasi peserta didik tinggi maka hasil kognitifnya tinggi dan sebaliknya. Menurut Suryabrata (2011) motivasi merupakan keadaan dalam pribadi orang yang mendorong individu untuk melakukan aktivitas-aktivitas tertentu untuk mencapai sesuatu tujuan. Motivasi ini dapat didorong seseorang untuk melakukan sesuatu. Sehingga motivasi ini disebut dengan faktor dari dalam diri karena semuanya muncul karena dari kemauan sendiri tanpa ada paksaan dari orang lain.

Berdasarkan analisis hubungan setiap indikator motivasi dengan hasil belajar, diketahui bahwa indikator yang mempengaruhi hasil belajar peserta didik adalah indikator minat, tekun, ulet dan cepat bosan. Dengan nilai kofisien Beta sebesar 0,23., 0,25., 0,30 dan, 0,21. Indikator minat menunjukan kesenangan peserta didik dalam mempelajari kimia. Dimana rata-rata peserta didik menjawab senang dan menyengkan belajar kimia, karena mudah dimengerti yang disampaikan oleh guru mata pelajaran kimia dan cara mengajar dengan berbagai metode yang asik. Indikator tekun adalah mengerjakan tugas hingga selesai dan berusaha lebih giat dalam memahami materi yang telah diajarkan, dimana rata-rata peserta didik mengatakan mereka berusaha mengerjakan dengan sungguh-sungguh dan selalu mempelajari kembali materi yang telah diajarkan sehingga dapat memahaminya. Indikator ulet aadalah terus belajar da tidak pernah putus asa dengan apa yang diperoleh, rata-rata peserta didik 
mengatakan selalu belajar untuk mendapatkan hasil yang lebih baik lagi dan jika diberikan tugas dan hasilnya salah mereka tetap ingin mengetahui kesalahannya dengan menanyakan kepada guru sehingga bias dipahami lagi. Untuk indikator cepat bosan yang dimaksudkan adalah peserta didik merasa cepat bosan dengan kegiatan pembelajaran yang secara berulang-ulang dengan materi yang sama. Dari hasil angket yang dijawab oleh peserta didik, rata- rata mereka mengatakan untuk lebih memperkuat ingatan tentang materi tersebut dan memahami lebih dalam lagi. Dari empat indikator tersebut yang sangat berpengaruh terhadap hasil belajar adalah indikator ulet, karena ulet berasal dari dalam diri peserta didik tanpa membutuhkan dorongan dari orang lain, sehingga jika keuletan peserta didik sangat besar maka menunjukan motivasi peserta didik tinggi untuk mencapai suatu tujuan.

Menurut Sardiman (2016) motivasi adalah serangkaian usaha untuk menyediakan kondisi-kondisi tertentu sehingga seseorang itu mau dan ingin melakukan sesuatu dan bila tidak suka maka berusaha untuk meniadakan atau mengelakkan perasaan tidak suka itu. Dalam kegiatan belajar, motivasi dapat dikatakan sebagai keseluruhan daya penggerak di dalam diri peserta didik yang menimbulkan kegiatan belajar yang menjamin kelangsungan dari kegiatan belajar dan memberikan arah pada kegiatan belajar, sehingga tujuan yang dikehendaki oleh subjek belajar itu dapat tercapai.

Peserta didik dengan motivasi belajar yang tinggi selalu mencapai keberhasilan yang besar dalam pembelajaran, sementara peserta didik yang kurang motivasi tidak melakukan upaya dalam proses pembelajaran dan sering gagal dalam ujian. Jika seorang peserta didik tidak memiliki motivasi, tidak mungkin mencapai kesuksesan sedangkan peserta didik yang bermotivasi tinggi dapat berhasil dalam kondisi apapun (Li \& Pan, 2009).

\section{SIMPULAN DAN SARAN}

Berdasarkan hasil analisis data penelitian dan pembahasan hasil penelitian, maka kesimpulan dari hasil penelitian ini adalah terdapat korelasi antara motivasi peserta didik dengan hasil belajar kimia kelas XI IPA SMA Negeri Se-Kecamatan Ternate Utara sebesar $88,0 \%$.

\section{DAFTAR RUJUKAN}

Azwar, S.2010. Reliabilitas dan Validitas. Yogyakarta: Pustaka Pelajar.

Az-Zahro, A.F. \& Khoirunnisa, R.N. 2017. Hubungan Antara Motivasi Belajar Dengan Prestasi Belajar Mata Pelajaran Kimia Siswa SMAN 1 Gedangan. Jurnal Psikologi Pendidikan, 4(3)

Jeffrey, D. I., \& Zein, A.2017. The Effects Of Achievement Motivation, Learning Discipline And Learning Facilities On Student Learning Outcomes, 7 (8).

Lestari, P.2014. Program Studi Pendidikan Guru Sekolah Dasar Fakultas Keguruan Dan Ilmu Pendidikan Tesis.Pontianak: Universitas Tanjungpura Pontianak.

Li, P. \& Pan, G. 2009. The Relationship between Motivation and Achievement-A Survey of the Study Motivation of English Majors in Qingdao Agricultural University. English Language Teaching, 2(1).http://www.ccsenet.org/journal/ index.php/elt/article/view/347 18 juli 2018

Ryan, K. E., Ryan, A. M., Arbuthnot, K., \& Samuels, M.2007. Students' Motivation for Standardized Math Exams. Educational Researcher, 36(1): 5-13.

Sardiman.2016. Interaksi dan Motivasi Belajar Mengajar. Jakarta: PT Raja Grafindo Prasada.

Slameto.2010. Belajar dan Faktor-Faktor yang Mempengaruhinya. Jakarta: Rineka Cipta.. 
Chemistry Education Review, Pendidikan Kimia PPs UNM, 2018, Vol.2, No.1 (24-31)

Sugiyono.2008. Metode Penelitian

Pendidikan: (Pendekatan

kuantitatif, kualitatif dan $R \& D$ ).

Bandung: Alfabeta.

Suryabrata, S.2011. Psikologi Pendidikan. Jakarta: Rajawali Pers.

Wardhana, A.2016. comparing the value of the effective contribution appears that learning motivation has a more dominant influence on learning achievement than the variable of disciplinary learning. Surakarta: Universitas Muhammadiyah Surakarta.

UU Nomor 20 Tahun 2013. Ststem Pendidikan Nasional 